CZASOPISMO INŻYNIERII LA¿OWEJ, ŚRODOWISKA I ARCHITEKTURY JOURNAL OF CIVIL ENGINEERING, ENVIRONMENT AND ARCHITECTURE JCEEA, t. XXXIV, z. 64 (3/II/17), lipiec-wrzesień 2017, s. 215-224, DOI:10.7862/rb.2017.166

\author{
Anna MARTYKA ${ }^{1}$ \\ Aleksandra PROKOPSKA ${ }^{2}$
}

\title{
WIELKOSKALARNE PROJEKTY REWITALIZACJI - WYBRANE PRZYKŁADY
}

\begin{abstract}
Miasta borykają się z wieloma problemami: przestrzennymi, społecznymi, ekonomiczno-gospodarczymi i ekologicznymi. Najbardziej uciążliwe dla ich zrównoważonego rozwoju, są: polaryzacja, suburbanizacja i rozrost nowych, monofunkcyjnych obszarów na peryferiach, obsługiwanych głównie za pomocą komunikacji samochodowej. W przeszłości tereny pełniące funkcje komunikacyjne, przemysłowe i portowe stanowiły wyizolowane obszary w strukturze urbanistycznej, niedostępne dla zwykłych mieszkańców i użytkowników. Wiele takich zdegradowanych i nieużytkowanych terenów może być ogromnym potencjałem w powiększaniu przestrzeni publicznych i zaspokajaniu potrzeb współczesnych mieszkańców. Miasta na całym świecie przystosowują się do nowych warunków w rozmaity sposób. Działania strategiczne, prowadzące do odzyskiwania obszarów zdegradowanych, zwłaszcza w centralnych partiach miast, są jednym z najważniejszych wyzwań dla władz samorządowych w Polsce, jeśli chodzi o tworzenie środowiska życia obywateli w duchu zasad zrównoważonego rozwoju. Warto zatem się przyjrzeć, jak inne miasta mierzą się z podobnymi wyzwaniami. Zaprezentowane w artykule realizacje są efektem wielkoskalarnych programów rewitalizacji, które wpisują się w całościową długofalową wizję rozwoju miast.
\end{abstract}

Słowa kluczowe: rewitalizacja, transformacja, rozwój zrównoważony, przestrzeń publiczna, miasto

\section{Wprowadzenie}

Ostatnie dekady przyniosły silną falę zainteresowania miastem rozumianym jako wielowarstwowa struktura porównywana do żywego organizmu [11]. Przyglądając się wielkim ośrodkom miejskim, można wyodrębnić zarówno nieko-

\footnotetext{
${ }^{1}$ Anna Martyka, Politechnika Rzeszowska, Zakład Projektowania Architektonicznego i Grafiki Inżynierskiej, al. Powstańców Warszawy 12, 35-959 Rzeszów; tel.: 17865 2110; e-mail: amartyka@prz.edu.pl

2 Aleksandra Prokopska, Politechnika Rzeszowska, Zakład Projektowania Architektonicznego i Grafiki Inżynierskiej, al. Powstańców Warszawy 12, 35-959 Rzeszów; tel.: 17865 1712; e-mail: aprok@prz.edu.pl
} 
rzystne zjawiska takie jak: niekontrolowany rozrost, fragmentacja, chaos, polaryzacja i atomizacja społeczna. Obecne są także pozytywne trendy: powrót do tradycyjnych wartości, ekologiczne i pro-społeczne działania, a także zwiększająca się świadomość włodarzy miast i mieszkańców, coraz częściej angażujących się $\mathrm{w}$ procesy partycypacyjne. Szansą na przeciwdziałanie negatywnym zjawiskom, a także pielęgnację tradycyjnych wartości i poszukiwanie nowych wymiarów związanych z rozwojem technologii informacyjnych są procesy rewitalizacyjne terenów miejskich, znajdujących z różnych powodów w kryzysie. Literatura przedmiotu $\mathrm{u}^{3}$ podaje wiele definicji rewitalizacji, ale najtrafniejsza dla prowadzonych w artykule rozważań jest ta, sformułowana przez Zbigniewa K. Zuziaka: ,(...) Rewitalizacja urbanistyczna to skoordynowane akcje inwestycyjne sektorów publicznego i prywatnego. Podejmowane jako reakcja na zjawiska degradacji tkanki miejskiej. Działania te powinny mieć cechy strategii ukierunkowanych na cele społeczne, ekonomiczne i kulturalne. Efekt tych przedsięwzięć powinien być trwały, strukturalny i wyrażać się wzrostem wartości, aktywności i atrakcyjności przestrzeni miejskiej” [16, s.107]. Jak wynika z przytoczonej powyżej definicji, tylko zintegrowane i skoordynowane działania rewitalizacyjne mają szansę poprawić jakość życia mieszkańców i zagwarantować rozwój społeczno-ekonomiczny całego miasta.

Jednym z podstawowych celów ożywiania zaniedbanych obszarów miasta jest zastosowanie kompleksowych zabiegów uczynić przestrzeń miejską bardziej przyjazną, bezpieczną, zwiększającą poczucie identyfikacji i odpowiedzialności mieszkańców. Pojawiające się coraz wyraźnej dążenie do uczynienia przestrzeni publicznej bardziej bezpieczną, jest spowodowane narastającymi w mieście współczesnym obawami społecznymi wynikającymi z ataków terrorystycznych, ale również konfliktów na tle rasowym i religijnym oraz nierozwiązanymi problemami z masowymi migracjami ludzi [4]. Poczucie bezpieczeństwa jest od początków historii osadnictwa traktowane jako jedna z najbardziej podstawowych potrzeb człowieka [6]. Innym problemem, oprócz tych zagrożeń o charakterze kryminalnym, jest zwiększająca się mobilność i aktywność mieszkańców. Odpowiednia organizacja komunikacji pieszej, rowerowej i samochodowej jest elementem kluczowym w programowaniu rozwoju miast [14]. W procesie rewitalizacji urbanistycznej istotna jest rola dobrej jakości przestrzeni publicznej, rozumianej jako powszechnie dostępne miejsce kultywowania więzi społecznych, wymiany informacji i poglądów, edukacji, budowania lokalnej tożsamości i poczucia bezpieczeństwa, wyrównania szans, integracji i asymilacji [10]. W intrygujący sposób ewoluowała przestrzeń publiczna miast od początku ich istnienia. Stopniowe metamorfozy i hybrydyzacja, polegająca a na łączeniu tra-

3 Wymienić należy najważniejszych autorów zajmujących się i propagujących rewitalizację w Polsce jak np. Baranowski, Chmielewski, Cielątkowska, Gasidło, Gorgoń, Kamrowska-Załuska, Kochanowski, Lorens, Markowski, Noworól, Ossowicz, Parterka, Paszkowski, Skalski, Ziobrowski, Zuziak. 
dycyjnych cech i funkcji ze współczesnymi tendencjami, to rezultat ciągłej adaptacji miasta do zmieniających się w czasie potrzeb i uwarunkowań, dodawania nowych znaczeń funkcji i form [3,8].

Niniejszy artykuł nie jest pracą o charakterze przekrojowym. Poruszane są w nim zagadnienia dotyczące planowania oraz efektów przekształceń zdegradowanych struktur miejskich o relatywnie znacznych rozmiarach. Metoda zastosowana w artykule bazuje na analizie doświadczeń wybranych subiektywnie obszarów poddanych transformacjom i opiera się na studiach literatury oraz badaniach terenowych głównie w miastach europejskich oraz w Nowym Jorku.

\section{Strategiczne projekty odnowy zdegradowanych terenów w miastach}

Obecnie poszukuje się optymalnych strategii organizacji i planowania miast, gwarantujących wysoki komfort życia mieszkańców. Procesy rewitalizacyjne wpisują się doskonale właściwie we wszystkie koncepcje programowania rozwoju miast. Wymienić tu należy koncepcje takie jak: idea miasta zwartego (compact city), inteligentnego (smart city), kreatywnego (creativecity), oszczędnego (economicalcity), odpornego (resistantcity), zielonego (greencity) oraz promującego aktywny styl życia (activecity). Rewitalizacja struktur miejskich jest jednym z najlepszych sposobów na przeciwdziałanie wielu problematycznym zjawiskom, występującymi $\mathrm{w}$ miastach, ponieważ wiąże się z dążeniem do oszczędnego gospodarowania zasobami przestrzennymi, z koncentracją funkcji i zabudowy, wzmacniania różnorodności funkcji i utrzymania jednorodności morfologicznej poszczególnych struktur przestrzennych. Jest to też bardziej efektywny i ekologiczny sposób zarządzania miastem, ponieważ ogranicza zużycie energii elektrycznej i potrzebę używania samochodów, ale także sprzyja lepszej utylizacji zanieczyszczeń i odpadów oraz ich powtórnego wykorzystania. Światowy rozgłos zyskały przeprowadzone w: Rotterdamie (Kop Van Zuid) Amsterdamie (Sporenburg, KNSM, Ijburg) Kopenhadze (IslandsBrygge i Qrestad) Hamburgu (HafenCity), Barcelonie (Besos-Forum i 22@bcn) Londynie (Docklands, OlimpicVillage 2012) Paryżu (Wielki Paryż 2030), Toronto (Port Lands) i Vancouver.

$\mathrm{Z}$ życiem w mieście wiąże się wzrost zagęszczenia i utrata przestrzeni, ale także równy dostęp do dóbr, które umożliwiają kontakt z naturą, parkami, nabrzeżami, co może pomóc mieszkańcom w redukcji stresu, poza tym przeciwdziała procesom wykluczania i sprzyja asymilacji. Wdrażanie procesów rewitalizacji nieużytków oraz obszarów zaniedbanych, zdegradowanych, przekształcanie ich w tereny zielone, często z zastosowaniem innowacyjnych technologii, pozwalających na wzrost i pielęgnację zieleni w trudnych warunkach miejskich, cieszy się rosnącą popularnością w miastach.

Procesy rewitalizacji nieużytkowanych nabrzeży miast mogą pomóc w odzyskaniu atrakcyjnych przestrzeni publicznych. Zaniedbane nabrzeża rzek, jezior 
czy mórz są zasobem terenów świetnie nadających się do pełnienia funkcji rekreacyjnych i wypoczynkowych. Na całym świecie cieszą się popularnością projekty zagospodarowania nabrzeży i przeznaczanie ich na parki linowe, z bogatą ofertą programową sportowo-rekreacyjną. Koncepcja tworzenia miejskich terenów zielonych $\mathrm{w}$ formie ciągłej sieci jest coraz częściej elementem całościowych strategii planistycznych, stanowiących jedno z podstawowych narzędzi rewitalizacji urbanistycznej [7].

Najlepszym przykładem odnowy wielkoobszarowych terenów nabrzeżnych jest Nowy Jork, który w ramach strategii rozwoju obszaru metropolitarnego wprowadza innowacyjny model programowania i zarządzania rozwojem miasta [5]. Wśród parków powstałych w ramach rewitalizacji poprzemysłowych i poportowych linii brzegowych jest Brooklyn Bridge Park (rys. 1.). Ten prawie 35 hektarowy teren zielony jest obecnie największym terenem zielonym zaraz po Prospekt Parku. Tereny starych doków i dawnego portu rzecznego wzdłuż brzegów rzeki East River, były od lat nieużytkowane i niedostępne. Autorem parku jest architekt krajobrazu Michaela Van Valkenburgh. Jest on autorem wielu projektów wielu założeń krajobrazowych w Ameryce. Brooklyn Bridge Park jest podzielony na różne strefy funkcjonalne, od placów zabaw dla dzieci poprzez platformy widokowe, plaże miejskie ścieżki dla biegaczy, skateparki, do stref dla sportów wodnych, przystanki dla promów i stref zieleni wysokiej.

W parku posadzono wyłącznie lokalne gatunki roślin. Warto pokreślić, że autor postarał się spełnić oczekiwania mieszkańców i ułatwił im bezpośredni dostęp do brzegu rzeki i wody. Na terenie parku umieszczone są zbiorniki gromadzące wody deszczowe, wykorzystywane powtórnie do nawadniana roślin [15]. Wszystkie parki znajdujące się na ternie Nowego Jorku posiadają własne centrum zarządzania, które odpowiedzialne jest za promocję i marketing, bieżące utrzymanie zieleni i infrastruktury, a także organizację wydarzeń kulturalnych i sportowo-rekreacyjnych [5].

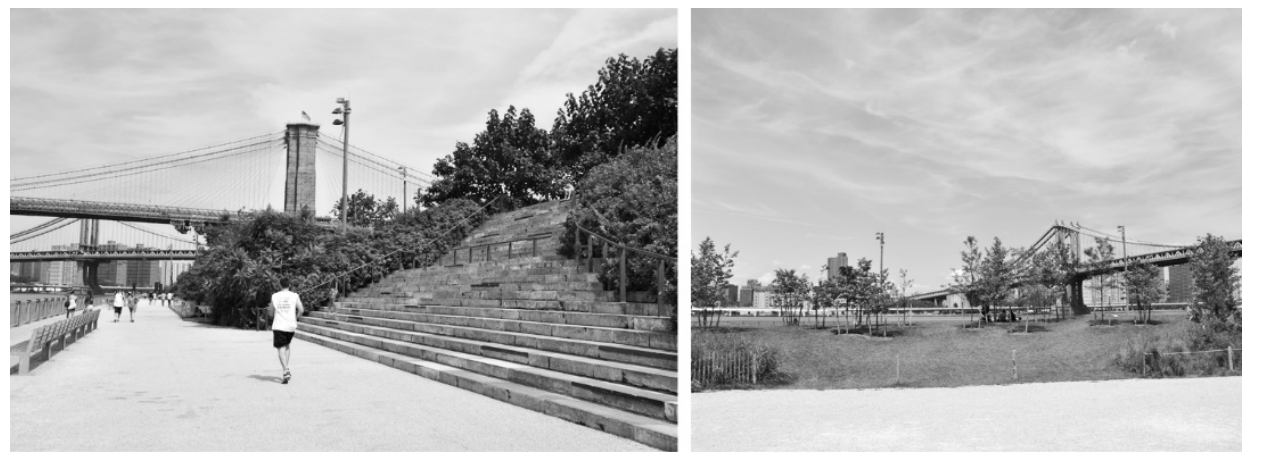

Rys. 1. Brooklyn Bridge Park w Nowym Jorku, źródło: A. Martyka

Fig. 1. Brooklyn Bridge Park in New York, source: A. Martyka 
Mieszkańcy współczesnych miast przemieszczają się pomiędzy przedmieściami a śródmieściem, pomiędzy miejscem zamieszkania a miejscem pracy. Szeroko rozumiana mobilność stała się już wyraźnym trendem socjologicznym, którego popularność rośnie. Rozbudowywane są węzły komunikacyjne, łączące różne środki transportu takie jak: tramwaje, autobusy, koleje, samoloty, rowery itd. Głównym bodźcem do podejmowania działań rewitalizacyjnych w obszarach o funkcjach komunikacyjnych jest uciążliwa tranzytowa komunikacja kołowa. Integracja ze środowiskiem miejskim i estetyzacja infrastruktury transportowej, wiąże się z koniecznością oszczędnego gospodarowania przestrzenią miejską oraz rosnącą konkurencją pomiędzy miastami, jak i wykorzystaniem potencjału przestrzeni $\mathrm{w}$ procesach rewitalizacyjnych, rozwojem kolejnictwa i innych środków transportu.
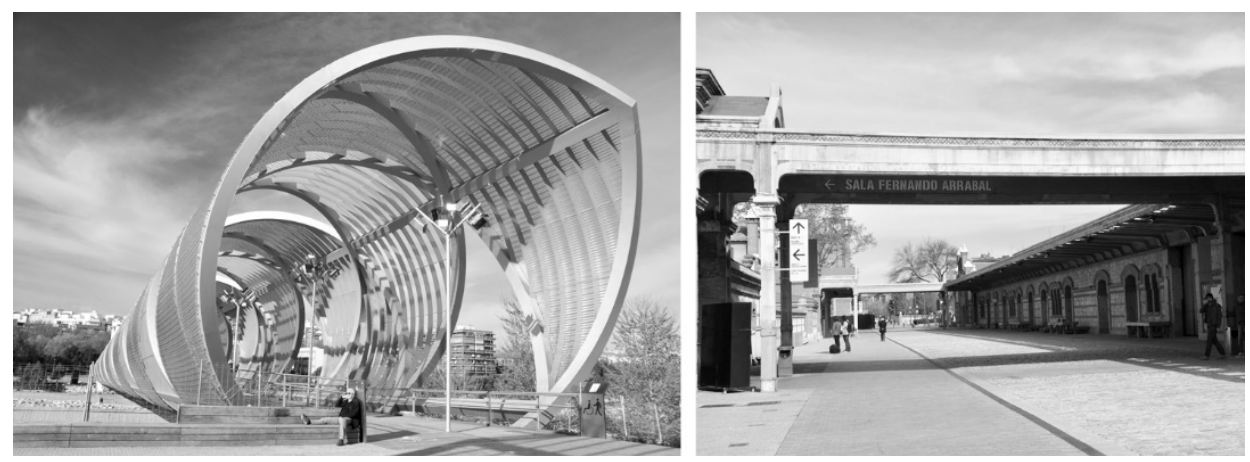

Rys. 2.Park Arganzuela w Madrycie, źródło: A. Martyka

Fig. 2. Arganzuela Park in Madrid, source: A. Martyka

Dobrym przykładem rewitalizacji terenów dotkniętych zjawiskami degradacji, spowodowanymi intensywną komunikacją samochodową jest Madryt. W 2004 roku władze Madrytu postanowiły przeciwdziałać pogarszającym się warunkom życia $\mathrm{w}$ mieście, poprzez umożliwienie mieszkańcom korzystania z rzeki, a także poprawę jakości zabudowy i przestrzeni publicznych. Aby ułatwić mieszkańcom kontakt $\mathrm{z}$ wodą w centralnym obszarze miasta, a także uwolnić tereny nabrzeżne pod przyszłe inwestycje, przeniesiono do tunelu 6,5kilometrowy odcinek autostrady M30 po obu brzegach rzeki Manzanares. Głównym celem transformacji urbanistycznej było stworzenie ogólnodostępnych przestrzeni publicznych o różnorodnym przeznaczeniu z dostępem do wody, połączenie centrum miasta $\mathrm{z}$ pozostałymi dzielnicami, poprawa jakości wody, ograniczenie ruchu samochodowego w centrum oraz przemiana zaniedbanych terenów w atrakcyjne, przyciągające mieszkańców miejsca (rys. 2.).

Program rewitalizacji terenów nadrzecznych miasta Madrid Rio (el Plan EspecialMadridRío), rozpoczęto w 2004 roku, a ostateczne zakończenie planowane jest w 2018 roku. W 2011 roku wykonano i oddano do użytku zrewitalizowane nabrzeża w samym centrum miasta. Największą część założenia krajo- 
brazowego zajmuje Park Arganzuela, liczący 33 hektary. W Parku Arganzuela motywem przewodnim jest woda. W strumieniach, korytach rzecznych usypanych z kamieniami woda wije się przez teren parku, wykorzystując jego zróżnicowaną topografię.

Dopiero po przekształceniach rzeka przestała być trudną do pokonania przeszkodą, którą pozostawała od najwcześniejszych lat w historii miasta, a tereny wokół niej przeobraziły się w atrakcyjne, liniowe przestrzenie publiczne, oferując mieszkańcom kontakt $\mathrm{z}$ wodą i przyrodą. Krajobraz koryta rzeki urozmaicają nowe kładki pieszo-rowerowe, jedna zaprojektowana przez Dominika Peroulatai dwie bliźniacze, w kształcie wieloryba, zdobione mozaikami artysty Daniela Canogara. Jedną z wielu atrakcji, która obecnie przyciąga zarówno mieszkańców, jak i turystów jest multidyscyplinarne centrum kultury MataderoMadrid, powstałe w zrewitalizowanych budynkach dawnej rzeźni.

Poszukuje się sposobów, a także wartościowych form zagospodarowania zdegradowanych terenów oraz nadania im nowych funkcji, włączenia ich w kontekst miejski, tak aby tworzyły synergiczny układ. Wiele miast na całym świecie wprowadza programy transformacji dużych obszarów przestrzeni miejskich. Najbardziej spektakularne działania realizowane są w metropoliach i mega-miastach. Są to długofalowe strategie dla rewitalizacji zaniedbanych i nieużytkowanych obszarów, terenów poprzemysłowych, czy też programy rewitalizacji zabytkowych centralnych stref, a także wielkopłytowych osiedli mieszkaniowych [13]. Obszarem, który znajduje się w trakcie procesów ożywiania, jest Greenwich Peninsula w Londynie - półwysep sąsiadujący od zachodu z Isle of Dok, a od wschodu z Dokami Królowej Wikorii. Wśród zdegradowanej struktury przestrzennej o przemysłowo-portowym rodowodzie, wyróżnia się biała bryła Millennium Dome (zwana obecnie areną O2), zaprojektowana przez biuro architektoniczne Richarda Rogersa i wybudowana na przełomie XX i XXI wieku.

Zatwierdzony w marcu 2015 roku przez władze Londynu plan zagospodarowania przestrzennego Greenwich Peninsula (rys. 3.) obejmuje obszar 74 hektarów. Ambitna rewitalizacja tego terenu wymagała zatwierdzenia jednego z największych w historii złożonego do akceptacji masterplanu, który był wyzwaniem także dla jego autorów. Cały proces rewitalizacji jest przewidywany na okres 15 lat i wspierany finansowo przez władze krajowe. Po tym czasie obszar ten ma stać się najbardziej ekologicznym terenem, o najniższej emisji dwutlenku węgla w kraju. Zastosowane zostaną rozwiązania redukujące zapotrzebowanie na energię i poprawiające jakość powietrza, oszczędne gospodarowanie wodą i odpadami komunalnymi zarówno w mieszkaniach, jak i w miejscach pracy. Co ciekawe, prace budowlane będą prowadzone w wyznaczone dni, tak aby ograniczyć niekorzystne działanie hałasu, drgań, pyłów w trakcie prac budowlanych [18]. 


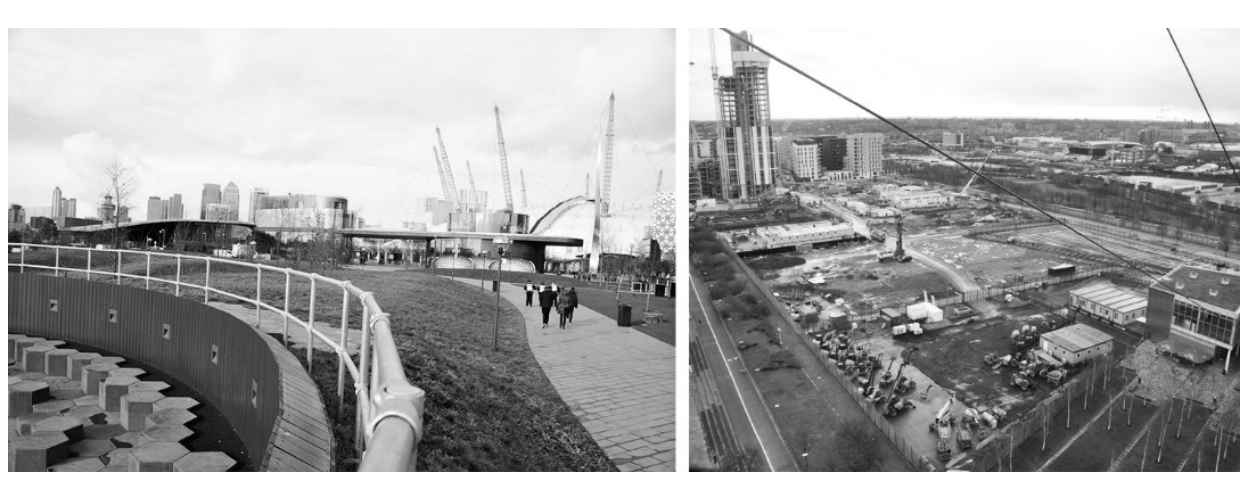

Rys. 3. Greenwich Peninsula w Londynie, źródło: A. Martyka

Fig. 3. Greenwich Peninsula in London, source: A. Martyka

W planie zdefiniowano kompozycję kwartałów miejskich, włączających istniejące już budynki, z siecią ulic, placów i parków. Wysokościowce mogą być lokowane tylko w najbliższym sąsiedztwie wieżowców na CanaryWharf. Przewiduje się stworzenie 15000 mieszkań, 12000 nowych miejsc pracy dla lokalnej społeczności, a także dwóch szkół dla 2000 uczniów, 5 kilometrów ścieżek do biegania, studia filmowego, dwóch hoteli, terminalu dla statków, szpitala, rozbudowę istniejącej uczelni artystycznej, przebudowę stacji metra i linii autobusowej oraz wiele różnego typu atrakcji [19]. Obecnie władze Londynu zwracają szczególną uwagę na stosowanie we wszystkich projektach zagospodarowania przestrzennego koncepcji mieszania różnorodnych funkcji miejskich, tzw. mix od use, powiązań pieszo-rowerowych, także tych z terenami nadrzecznymi oraz rozwiązań w zakresie zrównoważonego transportu publicznego i efektywności energetycznej.

\section{Podsumowanie}

Obszary rewitalizacji obok sprawnie funkcjonujących sieci transportu zbiorowego, przestrzeni publicznych i terenów zielonych, a także integracji poszczególnych jednostek strukturalnych, przyczyniają się do przeciwdziałania negatywnym zjawiskom przestrzennym, występującym w miastach tj.: suburbanizacji i kurczenia się centralnych rejonów miejskich oraz polaryzacji i rosnących nierówności społecznych [12].

Pojawia się coraz więcej projektów wielkoskalarnych, takich jak na przykład te, opisane w niniejszym artykule: Brooklyn Bridge Park, Madrid Rio i Greenwich Peninsula. Spowodowane jest to dużą podażą terenów zwłaszcza tych o poprzemysłowym, poportowym rodowodzie wymagających regeneracji, ale pojawiają się także globalne korporacje deweloperskie np. TishmanSpeyerPropoerties, które dążą do inwestycji i posiadają zdolność finansową do realizacji wielkich projektów o długim okresie zwrotu kapitału [9]. 
Procesy rewitalizacji struktur miejskich mające na celu ożywianie miejskich terenów o dużej powierzchni, powinny przebiegać w sposób integrujący instrumenty planowania strategicznego i planowania przestrzennego. Dotyczy to szczególnie koordynacji procesu rewitalizacji w dokumentach planowania przestrzennego, strategicznego i urbanistyki operacyjnej. Integrowanie różnych polityk miejskich, takich jak: polityka przestrzenna, kulturalna, społeczna, ekonomiczna, ekologiczna i infrastrukturalna, a także strategiczne zarządzanie sprzyjają tworzeniu policentrycznych, spójnych sprawnie funkcjonujących ośrodków miejskich. Wszelkie działania w strukturze urbanistycznej powinny być działaniami strategicznymi. Jak zauważa Zuziak, są to przede wszystkim mądre działania prowadzące do zmian w strukturze przestrzeni życia miejskiego w dłuższej perspektywie czasu [17].

Długofalowe strategie narażone są zazwyczaj na utrudnienia wynikające z nieprzewidywalności i zachodzących w szybkim tempie zmian [16]. Pomocą w kompleksowym planowaniu rozwoju miasta i rewitalizacji jego struktur jest odpowiednio opracowany scenariusz, przewidziany na miarę lokalnych możliwości i aspiracji włodarzy oraz potrzeb mieszkańców. Dlatego rozwiązania całościowe, z konsekwentnie realizowaną wizją, przy współudziale społeczeństwa dają gwarancję na udaną i atrakcyjną, wieloaspektową odnowę terenów, których potencjał to tej pory był niewykorzystany. W ten sposób powstaje atrakcyjna przestrzeń miejska, wkomponowująca się w inne przestrzenie miasta.

Miasta chcąc zwiększyć swój potencjał, nadążyć za światowymi trendami wzorując się na doświadczeniach innych ośrodków dokonują transformacji swoich obszarów. Mniejsze miasta podejmują zmiany mające na celu pozbycie się nadmiaru ruchu samochodowego ze śródmieść i tworzenie przyjaznych użytkownikowi sieci przestrzeni publicznych. W wyniku procesów rewitalizacji istniejącej tkanki miejskiej i na terenach poprzemysłowych powstają nowe ciekawe połączenia i zestawienia różnych typów przestrzeni publicznej. Istotnym miernikiem kondycji miasta jest jakość życia, czyli wartość sprzyjająca rozwojowi społeczności lokalnej ale również kluczowy element planowania strategicznego $\mathrm{w}$ tym marketingu terytorialnego [2]. W Polskich miastach pozostaje jeszcze wiele terenów dotkniętych zjawiskami degradacji, dla których szansą są właściwie przeprowadzone procesy rewitalizacyjne i przekształcenie ich w atrakcyjne tereny publiczne na miarę współczesnych potrzeb.

Miasta współzawodniczą między sobą. Rywalizacja i współzawodnictwo prowadzi nierzadko do osiągania nowych, ambitnych kierunków rozwoju, odkryć konstrukcyjno-technologicznych i rozwoju na polu architektury i urbanistyki. Benjamin Barber jest przekonany, że miasta powinny łączyć się w ramach globalnej sieci, wykorzystując potencjał komunikacji internetowej. Powinny jednoczyć swoje siły i wspólnie przeciwdziałać narastającym problemom, pomagać sobie nawzajem w reagowaniu na kryzysy, katastrofy i zagrożenia, a także czerpać inspirację i uczyć się od siebie nawzajem. Miasta powinny łączyć elementy lokalnej tradycji, z globalnymi trendami, jednocześnie pozostając 
otwarte na wpływy zewnętrzne oraz elastycznie dopasowując się do bieżących wymagań [1].

\section{Literatura}

[1] Barber B.: Gdyby burmistrzowie rządzili światem. Dysfunkcyjne kraje, rozkwitające miasta, MUZA SA Warszawa 2014.

[2] Damurski Ł.: Re-miasto. Scenariusze rozwoju urbanizacji w XXI wieku, Oficyna Wydawnicza Politechniki Wrocławskiej, Wrocław 2016.

[3] Gyurkovich M.: Hybrydowe przestrzenie kultury we współczesnym mieście europejskim, Wydawnictwo Politechniki Krakowskiej, Kraków 2013.

[4] Jasiński A.: Architektura w czasach terroryzmu. Miasto - przestrzeń publiczna budynek, Wolters Kluwer, Warszawa 2013.

[5] Jopek D.: Challenges of the NYC urban governance, [w:] Back to the Sense of the City: International Monograph Book. Centre de Política de SòliValoracions, p. 1209-1219, 2016, https://upcommons.upc.edu, [dostęp 15.02.2017].

[6] Norberg-Schulz C.: Bycie, przestrzeń i architektura, Warszawa 1999.

[7] Noworól A.: Rewitalizacja jako wyzwanie polityki rozwoju, [w:] O budowie metod rewitalizacji w Polsce - aspekty wybrane, red. Skalski K., s. 29-46, Monografie i Studia Instytutu Spraw Publicznych Uniwersytetu Jagiellońskiego, Kraków 2010, http://www-isp.miks.uj.edu.pl [dostęp 12.06.2017].

[8] Palej A.: Miasta cywilizacji informacyjnej. Poszukiwanie równowagi pomiędzy światem fizycznym a światem wirtualnym, Wydawnictwo Politechniki Krakowskiej, Kraków 2003.

[9] Piketty T.: Kapitał w XXI wieku, Wydawnictwo Krytyki Politycznej, Warszawa 2015.

[10] Prokopska A., Martyka A.: Miasto jako organizm przyjazny człowiekowi, [w:] Budownictwo i Architektura 16(1) 2017, s. 165-174, Wydawnictwo Uczelniane Politechniki Lubelskiej, Lublin 2017.

[11] Prokopska, A.: Morphology of the Architectural Achievement. A Methodological Analysis of Selected Morphological Systems of the Natural Architectural Environments, Journal of Transdisciplinary Systems Science, Oficyna Wydawnicza Politechniki Wrocławskiej, Wrocław 2002.

[12] Sassen S.: Expulsions: Beyond Inequality, wystąpienie na międzynarodowej konferencji Moving Cities: Contested Views on Urban Life, 29.06-1.07.2016, Kraków.

[13] Szczerek E.: Rola rewitalizacji osiedli mieszkaniowych w kreowaniu ciągłości i komplementarności przestrzeni publicznych współczesnego miasta, rozprawa doktorska, Wydział Architektury Politechniki Krakowskiej, Kraków 2017, http://suw.biblos.pk.edu.pl, [dostęp 12.07.2017].

[14] Wantuch-Matla D.: Przestrzeń publiczna 2.0. Miasto u progu XXI wieku, Księży Młyn, Łódź 2016.

[15] Wilczkiewicz M.: Kierunki rozwoju architektury krajobrazu w Stanach Zjednoczonych, Wydawnictwo Uniwersytetu Rolniczego, Kraków 2013. 
[16] Zuziak Z.: O tożsamości architektury, Wydawnictwo Politechniki Krakowskiej, Kraków 2008.

[17] Zuziak Z.: Strategie rewitalizacji przestrzeni śródmiejskiej, Monografia, Wydawnictwo Politechniki Krakowskiej, Kraków 1998.

[18] http://greenwichpeninsula.co.uk, [dostęp 12.07,2017]

[19] http://www.royalgreenwich.gov.uk, [dostęp 12.07,2017]

\section{LARGE-SCALE REVITALIZATION PROJECTS - SELECTED EXAMPLE}

\section{S u m m a r y}

Cities are facing many spatial, social, economic and environmental problems. The most troublesome for their sustainable development are polarization, sub-urbanization and growth of new mono-functional areas on peripheries supported mainly with the road transport communication. In the past, areas performing communication, industrial and port functions were isolated areas in the urban planning structure, unavailable to ordinary residents and users. A lot of such degraded and not-used areas can be a great potential in enlarging public spaces and meeting the needs of contemporary residents. Cities worldwide are adapting to new conditions in various ways. Strategic actions leading to regain degraded areas, especially in central parts of cities, are one of the most important challenges for self-government authorities in Poland, when it comes to creating living environment of citizens in the spirit of sustainable development. Therefore, it is worth to take a look, how other cities respond to similar problems. Implementations presented in the article are an effect of large-scalar revitalization program, which becomes a part of comprehensive long-term vision of the urban development.

Keywords:revitalization, transformation, sustainable development, public space, city

Przestano do redakcji: 09.06.2017 r.

Przyjęto do druku: 01.09.2017 r. 